\title{
The Use of Hand-held GPS Receivers for the Identification of Objects in a Wooded Area
}

\section{Introduction}

This paper is of a research - cognitive feature. It presents a methodology for the identification of point objects (trees) in a wooded area, having an average degree of terrain details condensation and small denivelation of the terrain. The applied methodology was based on the use of hand-held GPS receivers with navigation applications and functions.

The advantage of the presented method is the speed and relatively low cost of development. In the economic and technical aspect the presented method for identifying trees may be applied in practice, eg. by the forest service. (Of course, using one of three types of receivers, and not all at the same time - as has been the case for the research). It can be used not only for labeling or identification of individual species of trees, but for example feeding grounds, waterholes and any peculiarities occurring in the area. In addition, positioned and placed on the local thematic maps (eg. travel maps) places particularly worth a look or even those that should be avoided due to the risk of, which may occur in them, may affect the improvement of the quality of tourist information. They can also serve the purpose of the promotion of the region.

Navigation devices used in the field and described in this publication provide the accuracy of coordinates determination (positioning) even of 2-3 meters [4] for some point objects and can be used for updating the maps and thematic databases of topographic objects.

\section{The State of Research}

In terms of research on the use of GNSS and GPS equipment in specific field conditions, which for this type of measurement are wooded areas, there are a few studies in the form of publications. From the point of view of the subject presented in the

\footnotetext{
* University of Agriculture in Krakow, Poland
} 
title of this paper, [7] deserves attention - elaboration, in which the authors in a synthetic way show the specificity of GNSS measurements in the forest area using different classes of receivers and selected measurement modes. In turn [5] describes the preliminary results of experiments with the use of EGNOS system, made with the Garmin GPSmap 76CSx receiver. Later studies [6] showed an acceptable accuracy and precision of the manual GPS receiver with the EGNOS signal. On the identification of surface objects (plots), and their key attribute (areas) was written in papers [2] and [3]. These works show that GPSmap 76 Garmin receivers were used in the Single Area Payment Scheme for the determination of the areas of plots and they met the criteria of precision regarding the control of applications submitted by farmers (concerning the direct payments for crops). And in [4] has been shown, that in specific cases GPSmap 76 receivers, the Nautiz X7 and GPSmap 62st - can be used as tools to obtain data for thematic maps updates for your reference for illustrative purposes.

These receivers may thus serve (to a limited extent) for the identification of point or surface objects on the ground depending on the type and degree of the density of situational objects.

\section{Methodology}

The study used partly the database of 2013 [1]. The author in this paper made the thematic map and database for 12 natural monuments for the stand inventory purposes. Measurements which are the subject of analysis of this paper were made one year later. Measurements were carried out with the two navigation type, handheld receivers GPSmap 76, Garmin GPSmap 62st, completing and verifying them with the receiver of a wider range of applications - Nautiz X7, in which the map was recorded as an orthophotomap. Thus, three independent measurements of the same objects were made by means of three different types of receivers. In the case of the tested receivers, data obtained using the Nautiz X7 are the most similar to the actual.

The aim of the study was to determine the differences in the obtained coordinates using different types of GPS receivers. In each of the receivers EGNOS correction was enabled, increasing the accuracy of coordinates determination by the receiver. In order to record the coordinates of an object using GPSmap 76 and GPSmap 62 - "waypoint" function was used and then the "mark" key to save the points in the memory of each of the receivers. In both cases, an "averaged position" function was used, which increases the accuracy of positioning.

In the next stage of the work, the transfer of data from the receivers to the computer was carried out and then they were developed in the office. Coordinate transformation was performed from the WGS84 system to geodetic System 1992, so that the differences of points coordinates values measured using the above mentioned types of GPS receivers, were expressed in metric measure rather than in degrees. It should be noted that the standard settings of these GPS receivers enable obtaining of the geographical coordinates $(\mathrm{N}, \mathrm{E})$. 
Despite obstacles partially covering the horizon (limiting the scope and power of the reception of the satellite signals used for positioning points), for 8 of the 12 test items direct and clearly defined access was obtained. This means that 3 of the 12 trees were found by the navigation function "find" with the use of additional databases in the form of attribute table with the description and picture of the monument of nature. These three cases of identification of trees (1,6 and 9) require the use of a table of descriptive and graphics attributes from the database of a group of natural monuments, located in the area of research. The cause of the equipment failure in this regard was the fact that there are these trees in a large cluster, in the presence of other tall trees nearby. It should be remembered that the tested receivers need an open horizon to be able to position accurately enough. In addition, their accuracy is low enough that the positioned point can be found within a radius of 2-7 meters from the indicated position in the "waypoint" mode. In the case of measured trees, the situation is simplified because they are always visible in the field and can be recognized in sight. With additional descriptive database with information on the species, diameter and tree photo - we can clearly identify it in a wooded area with no risk of confusion. The main objective of the research is to determine the size of the differences in the positioning using different types of hand-held receivers obtained by registering the coordinates and their mutual comparison.

\section{Results}

Table 1 shows the results of the coordinates measurement with the use of three types of GPS receivers: Nautiz X7, GPSmap 76 and GPSmap 62st. The coordinates are expressed in degrees in WSG84 system. In the following part of the study the calculated differences between the coordinates of the points will be presented (obtained using the above mentioned types of receivers).

Table 1. The list of results of point objects coordinates measuring in the system WGS84

\begin{tabular}{||c|c|c|c|c|c|c||}
\hline \multirow{2}{*}{ No. } & \multicolumn{2}{|c|}{ Nautiz X7 } & \multicolumn{2}{c|}{ GPSmap 76 } & \multicolumn{2}{c||}{ GPSmap 62st } \\
\cline { 2 - 7 } & $X 1[\mathrm{~m}]$ & Y1 [m] & X2 [m] & Y2 [m] & X3 [m] & Y3 [m] \\
\hline \hline 1 & 19.237960 & 49.959246 & 19.237861 & 49.959250 & 19.237859 & 49.959240 \\
\hline 2 & 19.239348 & 49.959662 & 19.239306 & 49.959722 & 19.239340 & 49.959700 \\
\hline 3 & 19.239675 & 49.959663 & 19.239639 & 49.959694 & 19.239679 & 49.959664 \\
\hline 4 & 19.240395 & 49.959845 & 19.240361 & 49.959861 & 19.240388 & 49.959851 \\
\hline 5 & 19.240855 & 49.959960 & 19.240806 & 49.959972 & 19.240856 & 49.959962 \\
\hline 6 & 19.243181 & 49.960445 & 19.243250 & 49.960472 & 19.243299 & 49.960469 \\
\hline 7 & 19.237187 & 49.960897 & 19.237225 & 49.960936 & 19.237199 & 49.960966 \\
\hline 8 & 19.237660 & 49.961408 & 19.237583 & 49.961361 & 19.237613 & 49.961391 \\
\hline 9 & 19.235452 & 49.959996 & 19.235333 & 49.959944 & 19.235410 & 49.959983 \\
\hline 10 & 19.234489 & 49.960937 & 19.234420 & 49.960936 & 19.234457 & 49.960954 \\
\hline 11 & 19.235229 & 49.959307 & 19.235247 & 49.959314 & 19.235244 & 49.959311 \\
\hline 12 & 19.236784 & 49.959392 & 19.236806 & 49.959361 & 19.236797 & 49.959399 \\
\hline
\end{tabular}


For a better reading of the differences between the obtained coordinates of the point objects a transformation from the WGS84 coordinate system to 1992 system was made. In this way the obtained results are given in metric measure. The coordinate values after transformation are shown in Table 2. Table 3 presents a list of coordinate differences for given objects in a metric measure and basic statistical analyses. Red color highlights objects that required using an existing database for identification in the field.

Table 2. The list of the coordinates after the transformation in the system after 1992

\begin{tabular}{|c|c|c|c|c|c|c||}
\hline \multirow{2}{*}{ No. } & \multicolumn{2}{|c|}{ Nautiz X7 } & \multicolumn{2}{c|}{ GPSmap 76 } & \multicolumn{2}{c|}{ GPSmap 62st } \\
\cline { 2 - 7 } & X1 [m] & Y1 [m] & X2 [m] & Y2 [m] & X3 [m] & Y3 [m] \\
\hline \hline 1 & 517063.2 & 232465.7 & 517056.1 & 232466.2 & 517055.9 & 232465.0 \\
\hline 2 & 517162.6 & 232512.3 & 517159.5 & 232519.0 & 517162.0 & 232516.5 \\
\hline 3 & 517186.0 & 232512.5 & 517183.4 & 232515.9 & 517186.3 & 232512.6 \\
\hline 4 & 517237.6 & 232532.9 & 517235.1 & 232534.6 & 517237.1 & 232533.5 \\
\hline 5 & 517270.5 & 232545.8 & 517267.0 & 232547.1 & 517270.6 & 232546.0 \\
\hline 6 & 517437.1 & 232600.2 & 517442.1 & 232603.2 & 517445.6 & 232602.9 \\
\hline 7 & 517007.2 & 232649.0 & 517009.9 & 232653.4 & 517008.0 & 232656.7 \\
\hline 8 & 517040.9 & 232706.0 & 517035.4 & 232700.7 & 517037.5 & 232704.1 \\
\hline 9 & 516883.1 & 232548.5 & 516874.6 & 232542.7 & 516880.1 & 232547.1 \\
\hline 10 & 516813.7 & 232652.9 & 516808.8 & 232652.8 & 516811.4 & 232654.8 \\
\hline 11 & 516867.3 & 232471.9 & 516868.6 & 232472.7 & 516868.4 & 232472.3 \\
\hline 12 & 516978.8 & 232481.7 & 516980.4 & 232478.3 & 516979.7 & 232482.5 \\
\hline
\end{tabular}

Table 3. List of coordinate differences

\begin{tabular}{||l|c|c|c|c|c|c||}
\hline $\begin{array}{c}\text { Observation number/ } \\
\text { basic statistics }\end{array}$ & $\begin{array}{c}\mathrm{X} 1-\mathrm{X} 2 \\
{[\mathrm{~m}]}\end{array}$ & $\begin{array}{c}\mathrm{X} 1-\mathrm{X} 3 \\
{[\mathrm{~m}]}\end{array}$ & $\begin{array}{c}\mathrm{X} 2-\mathrm{X} 3 \\
{[\mathrm{~m}]}\end{array}$ & $\begin{array}{c}\mathrm{Y} 1-\mathrm{Y} 2 \\
{[\mathrm{~m}]}\end{array}$ & $\begin{array}{c}\mathrm{Y} 1-\mathrm{Y} 3 \\
{[\mathrm{~m}]}\end{array}$ & $\begin{array}{c}\mathrm{Y} 2-\mathrm{Y} 3 \\
{[\mathrm{~m}]}\end{array}$ \\
\hline 1 & 7.1 & 7.2 & 0.1 & -0.4 & 0.7 & 1.1 \\
\hline 2 & 3.0 & 0.6 & -2.4 & -6.7 & -4.2 & 2.4 \\
\hline 3 & 2.6 & -0.3 & -2.9 & -3.4 & -0.1 & 3.3 \\
\hline 4 & 2.4 & 0.5 & -1.9 & -1.8 & -0.7 & 1.1 \\
\hline 5 & 3.5 & -0.1 & -3.6 & -1.3 & -0.2 & 1.1 \\
\hline 6 & -5.0 & -8.5 & -3.5 & -3.0 & -2.7 & 0.3 \\
\hline 7 & -2.7 & -0.8 & 1.9 & -4.3 & -7.7 & -3.4 \\
\hline 8 & 5.5 & 3.4 & -2.1 & 5.2 & 1.9 & -3.3 \\
\hline 9 & 8.5 & 3.0 & -5.5 & 5.8 & 1.5 & -4.4 \\
\hline 10 & 4.9 & 2.3 & -2.6 & 0.2 & -1.9 & -2.0 \\
\hline 11 & -1.3 & -1.1 & 0.2 & -0.8 & -0.4 & 0.4 \\
\hline 12 & -1.6 & -1.0 & 0.7 & 3.5 & -0.8 & -4.2 \\
\hline Standard deviation & 4.1 & 3.7 & 2.1 & 3.8 & 2.7 & 2.7 \\
\hline The arithmetic mean & 2.3 & 0.4 & -1.8 & -0.6 & -1.2 & -0.6 \\
\hline Sum of the squares & 247.8 & 153.3 & 89.2 & 163.0 & 95.4 & 84.2 \\
\hline $\begin{array}{l}\text { Mean square error of the } \\
\text { difference of coordinates }\end{array}$ & 4.7 & 3.7 & 2.8 & 3.8 & 2.9 & 2.8 \\
\hline Max & 8.5 & 7.2 & 1.9 & 5.8 & 1.9 & 3.3 \\
\hline Min & -5.0 & -8.5 & -5.5 & -6.7 & -7.7 & -4.4 \\
\hline \hline
\end{tabular}


Figure 1 illustrates the dispersion of coordinates differences in the $X$ direction. The Figure 2 shows the dispersion of coordinate differences on the $\mathrm{Y}$ axis. These drawings show substantial differences in the positioning of the same points - using various types of receivers.

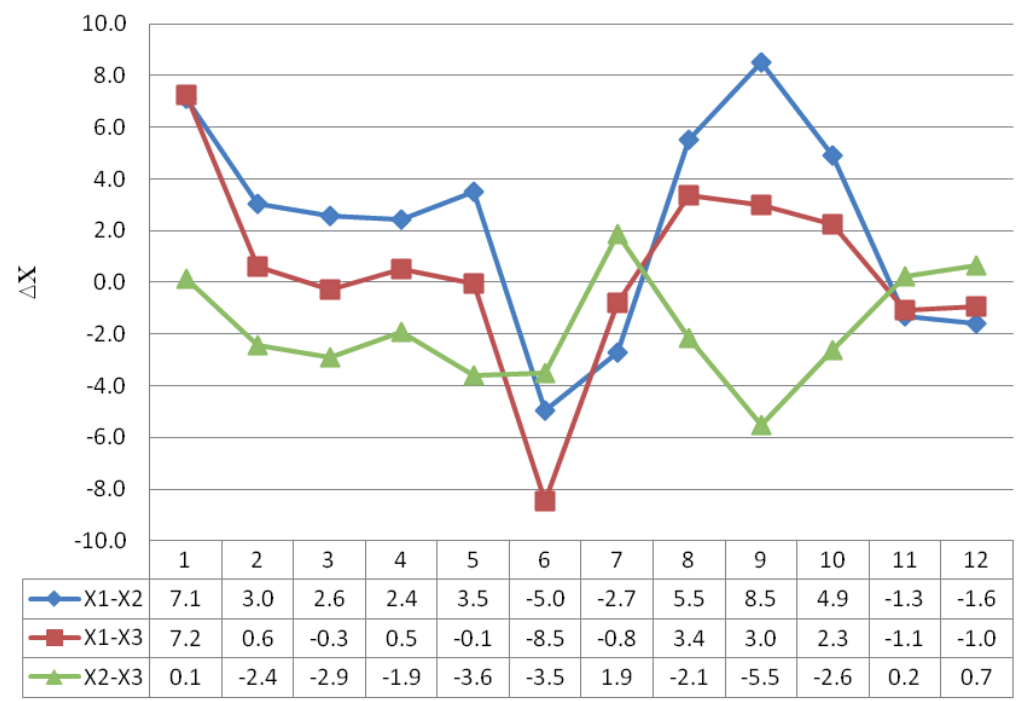

Fig. 1. A scatterplot of coordinates differences in the $X$ axis direction

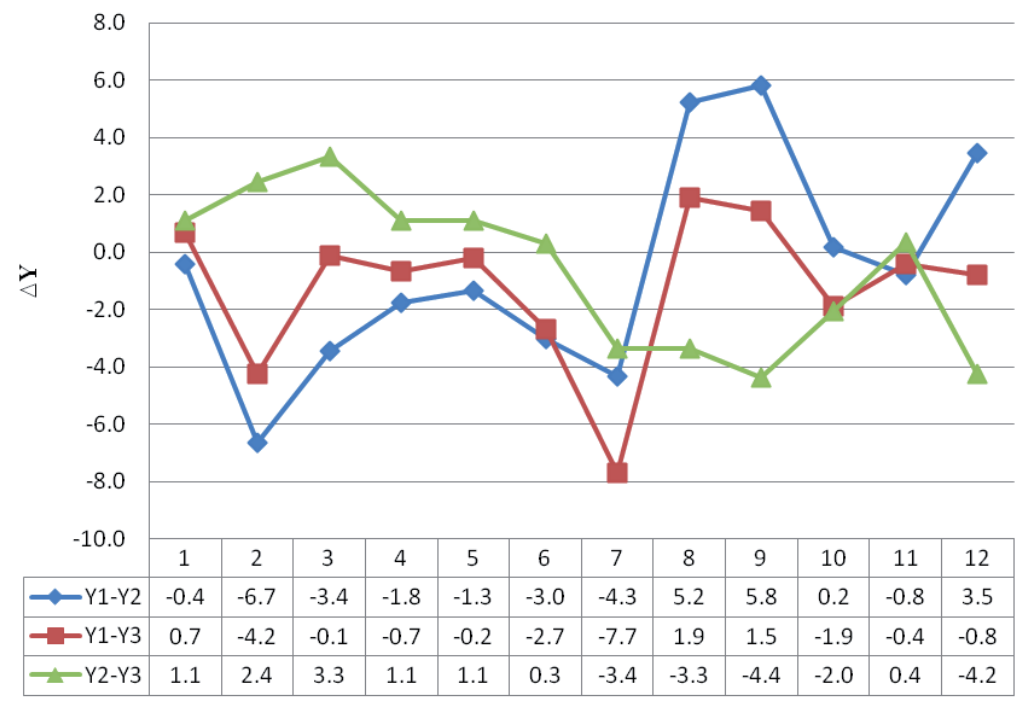

Fig. 2. A scatterplot of coordinates differences in the $Y$ axis direction 
In the next graph (Fig. 3) there is the trail marked when registering the coordinates of individual points (trees) and traveled route. The results of coordinate registration with the use of the receiver GPSmap 76 are marked in red. The results of the coordinate registration with the use of the receiver GPSmap 62st are marked in green. The results of the coordinate registration with the use of the receiver Nautiz X7 are marked in blue. In this figure, the mutual distances between the measured trees can be seen. They apparently do not seem to be large. After the calculation (from coordinates) of the mutual distances of the positioned points, the essence of the problem can be seen.

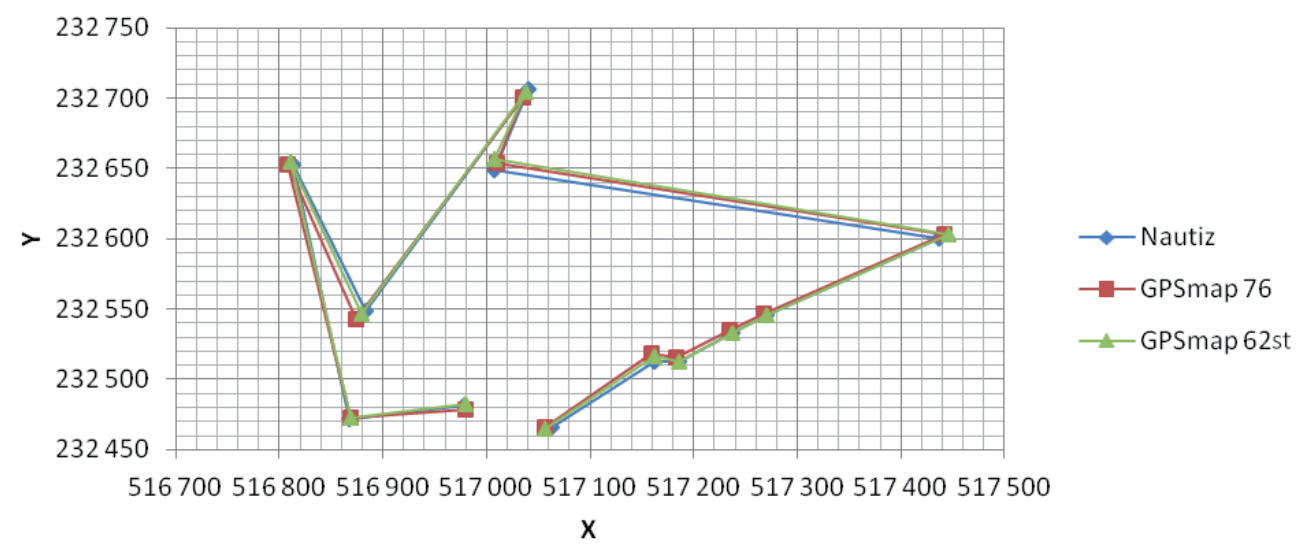

Fig. 3. Relative positions of the trees based on the recorded points and the trace of the travelled path

Table 4 summarizes the calculated displacement vectors of the points positioned using different types of receivers.

Table 4. List of displacement vectors for the points positioned using different types of receivers

\begin{tabular}{||l|c|c|c||}
\hline $\begin{array}{c}\text { Observation number/ } \\
\text { basic statistics }\end{array}$ & $\begin{array}{c}\text { Nautiz X7-GPSmap 76 } \\
{[\mathrm{m}]}\end{array}$ & $\begin{array}{c}\text { Nautiz X7-GPSmap 62st } \\
{[\mathrm{m}]}\end{array}$ & $\begin{array}{c}\text { GPSmap 76-GPSmap 62st } \\
{[\mathrm{m}]}\end{array}$ \\
\hline \hline 1 & 7.1 & 7.3 & 1.1 \\
\hline 2 & 7.3 & 4.3 & 3.5 \\
\hline 3 & 4.3 & 0.3 & 4.4 \\
\hline 4 & 3.0 & 0.8 & 2.2 \\
\hline 5 & 3.8 & 0.2 & 3.8 \\
\hline 6 & 5.8 & 8.9 & 3.5 \\
\hline 7 & 5.1 & 7.7 & 3.8 \\
\hline 8 & 7.6 & 3.9 & 4.0 \\
\hline 9 & 10.3 & 3.3 & 7.0 \\
\hline 10 & 4.9 & 2.9 & 3.3 \\
\hline
\end{tabular}


Table 4. cont.

\begin{tabular}{||l|c|c|c||}
\hline 11 & 1.5 & 1.2 & 0.4 \\
\hline 12 & 3.8 & 1.2 & 4.3 \\
\hline Standard deviation & 2.4 & 3.0 & 1.7 \\
\hline The arithmetic mean & 5.4 & 3.5 & 3.4 \\
\hline Sum of squares & 410.8 & 248.8 & 173.4 \\
\hline Mean square error & 6.1 & 4.8 & 4.0 \\
\hline Max & 10.3 & 8.9 & 7.0 \\
\hline Min & 1.5 & 0.2 & 0.4 \\
\hline
\end{tabular}

The smallest differences show results for the coordinates obtained using GPSmap 76 and GPSmap 62st because these receivers are of the same class of accuracy. The average differences of positioning between the presented types of receivers range approximately between $3.5 \mathrm{~m}$ and $5.5 \mathrm{~m}$.

\section{Conclusions}

On the basis of the tests can be concluded, that the results presented in this publication show, dependent on the field conditions, capabilities for handheld receivers for the identification of point objects in a wooded area.

Tested receivers are suitable for the identification of point objects in the space of the forest in a limited way and can be used only for guidance and illustrative purposes.

The presented methodology can be used to a limited extent for tourist map updates or for regions promotional purposes. Knowing the coordinates of point objects it is possible to use the FIND function to find the object on the ground using each of the mentioned receivers: GPSmap 76, GPSmap 62st oraz Nautiz X7. And [4] the positioning accuracy of the receivers in the open area with enabled WAAS / EGNOS is respectively for GPSmap 76 (7-10 m), GPSmap 62st (3-5 m) and Nautiz X7 (2 m). Note, however, that in the space of wooden area the accuracy is lower.

\section{References}

[1] Czembor A.: Wykorzystanie GPSmap 76 i GPS Nautiz do prac inwentaryzacyjnych zespotu pałacowo-parkowego w Osieku. Uniwersytet Rolniczy w Krakowie, 2013 [E.Sc. thesis].

[2] Kwinta A., Szeptalin A.: Wykorzystanie ręcznych odbiorników GNSS do pomiarów powierzchni działek rolnych. Infrastruktura i Ekologia Terenów Wiejskich, nr 6, 2010, pp. 157-166.

[3] Mika M.: Wykorzystanie ręcznych odbiorników GPS w Systemie Jednolitej Płatności Obszarowej dla wyznaczenia pól powierzchni działek. Infrastruktura i Ekologia Terenów Wiejskich, nr 3, 2011, pp. 53-62. 
[4] Mika M.: Examination of the Capabilities of Some Models of Hand GPS Receivers for Purposes of Creation of Thematic Maps. Geomatics and Environmental Engineering, vol. 8, no. 2, 2014, pp. 47-56.

[5] Siejka M.: Wstępne wyniki eksperymentów z wykorzystaniem systemu EGNOS, wykonanych za pomoca odbiornika Garmin GPSMap 76CSx. Zeszyty Naukowe Akademii Rolniczej im. Hugona Kołłątaja w Krakowie, nr 431, Geodezja, z. 22, 2006, pp. 177-184.

[6] Siejka Z.: Analiza aktualnych dokładności i precyzji ręcznego odbiornika GPS z sygnałem EGNOS. Infrastruktura i Ekologia Terenów Wiejskich, nr 1/II, 2012, pp. 121-128.

[7] Szostak M., Wężyk P.: Pomiary GNSS w przestrzeni leśnej przy wykorzystaniu różnej klasy odbiorników oraz wybranych technik pomiaru. Archiwum Fotogrametrii, Kartografii i Teledetekcji, vol. 25, 2013 pp. 217-231. 